\title{
EFFECT OF COGNITIVE BEHAVIORAL THERAPY FOR SEROTONIN LEVEL, DEPRESSION SCORE AND QUALITY OF LIFE IN CERVICAL CANCER PATIENTS
}

\author{
Soetrisno, Sri Sulistyowati, Supriyadi Hari Respati, Muhamad Nasrudin \\ Department of Obstetric and Gynecology \\ Faculty of Medicine Sebelas Maret University Surakarta.
}

\begin{abstract}
ABSTRAK
Kanker serviks adalah penyebab paling umum kematian di antara neoplasma ginekologi. Saat ini manajemen kanker serviks stadium lanjut belum mampu meningkatkan prognosa. Terapi intervensi standar, kemoterapi dan radioterapi, serta nyeri yang muncul bisa menyebabkan stres psikologis hingga depresi, sehingga mengurangi kualitas hidup pasien. CBT untuk stres psikologis dan depresi diharapkan dapat meningkatkan keberhasilan terapi standar. Serotonin adalah neurotransmitter yang berperan dalam depresi patofisiologi. Tujuan dari penelitian ini adalah untuk menganalisis pengaruh kognitif terapi perilaku pada tingkat serotonin, skor depresi dan kualitas hidup pada pasien kanker serviks staidum lanjut dengan menggunakan metode pra dan pasca desain uji quasi eksperimental. Sampelnya adalah 15 orang masing-masing di kelompok intervensi dan kelompok kontrol. Kelompok intervensi diberikan CBT dan terapi standar, sedangkan kelompok kontrol hanya diberi terapi standar saja. Penelitian dilakukan di Departemen Obstetri dan Ginekologi Rumah Sakit Dr Moewardi Surakarta dan Laboratorium Prodia, Januari-Maret 2015. Variabel bebasnya adalah pasien kanker serviks stadium lanjut yang menjalani CBT intervensi dan variabel tergantungnya adalah tingkat serotonin, skor depresi dan skor kualitas hidup. Hasilnya, tingkat serotonin dan skor kualitas hidup lebih tinggi setelah intervensi dibandingkan dengan kontrol, (219,43 $\pm 33,42$ vs 89,57 $\pm 23,23)$ dan $(85,13 \pm 14,62$ vs 41,86 $\pm 7,24)$, masing-masing. Skor depresi lebih rendah setelah intervensi tanpa CBT (11.20 44.94 vs $17.00 \pm 4.86)$ dan signifikan secara statistik (p <0,05). Jadi, ada pengaruh dari terapi perilaku kognitif pada tingkat serotonin, skor depresi dan kualitas hidup pada pasien kanker serviks stadium lanjut dan secara statistik signifikan. (FMI 2016;52:231-234)
\end{abstract}

Kata kunci: kanker serviks stadium lanjut, serotonin, skor depresi, kualitas hidup, CBT

\begin{abstract}
Cervical cancer is the most common cause of death among gynaecological neoplasms. Management of advanced cervical cancer currently has not been able to improve the prognosis. Standard intervention therapy, chemotherapy and radiotherapy, as well as the emerging pain could lead to psychological stress till depression, thus reduce patients' quality of life. CBT for psychological stress and depression is expected to improve the fruitfulness of standard therapy. Serotonin is a neurotransmitter which plays a role in the patophysiology of depression. The aim of this study is to analyze the effect of cognitive behavioral therapy on serotonin level, depression score and quality of life in advanced cervical cancer patient with experimental quasi pre and post test design methods. The samples are 15 subjects in both intervention and control groups. Intervention group was given CBT and standard therapy, while control group was given standard therapy only. Study was held in Department of Obstetric and Gynecologic Dr. Moewardi Hospital Surakarta and Prodia Laboratory, in January to March 2015. Independent variable was advanced cervical cancer patients underwent CBT intervention and dependent variables were serotonin level, depression score and quality of life score. The result, serotonin level and quality of life scores were higher after intervention compared with control, $(219.43 \pm 33,42$ vs $89.57 \pm 23.23)$ and $(85.13 \pm 14.62 \mathrm{vs} 41.86 \pm 7.24)$, respectively. Depression score was lower after intervention than without CBT intervention (11.20 \pm 4.94 vs 17.00 \pm 4.86$)$ and statistically significant $(p<0.05)$. So, there were effects of cognitive behavioural therapy on serotonin level, depression score and quality of life score in cervical cancer patients and were statistically significant. (FMI 2016;52:231-234)
\end{abstract}

Keywords: advanced cervical cancer, serotonin, depression score, quality of life, CBT

Correspondence: Soetrisno, Department of Obstetric and Gynecology, Faculty of Medicine Sebelas Maret University, Surakarta, Indonesia. Phone: 0816672564. e-mail: soetrisno_spogk@yahoo.com

\section{INTRODUCTION}

Cervical cancer is a malignant neoplasm of cervix, triggered by human papilloma virus (HPV) high risk oncogenic group, particularly HPV 16, 18 and its philogenics (Himpunan Onkologi Ginekologi Indonesia 2013). According to World Health Organization
(WHO), it takes the second place among diseases that cause death in women around the world. There are 7.7 cases with the mortality rate reaches 2.3 per 100,000 women every year (Surveillance Epidemiology and End Result Program 2012). According to International Agency for Research on Cancer (IARC) it is the most common malignancy in Indonesia, i.e approximately 
$34.4 \%$ of entire cancer incidences, $70 \%$ suffer advanced stadium with low survival rate. Every year there are 15,000 new cases with 8,000 deaths (IARC 2005). In Indonesia, cervical cancer is the most common malignancy attacks women in productive age. At the age of 30-50 years old, women who had been having sexual contact will have higher risk to cervical cancer. Patients diagnosed with advanced cervical cancer still dominate because of late diagnosis or they were too late to seek the health care centers. It is due to the low socioeconomical status and education level, as well as the lack of infrastructures and sources availability (Prawiroharjo 2010). Advanced cervical cancer sufferers often experienced physical, emotional, and social stress, even depression, and pain due to tumor metastasis, e.g bones, muscles, skin and vessels metastasis, thus influence the quality of life. Assumption that cancer is a deadly disease cause fear so the patients' families often isolate them and this adds more continuous stress (Schiff 2003).

Serotonin plays an active role in delivering emotional messages, controlling behavior and psychological response toward environmental stressors, and is involved in the patophysiology of depression. Several studies have implied serotonin system (5-HT) and Hipotalamus-Pituitary-Adrenal (HPA) axis disturbances as the most consistent neurobiological changes associated with depression tendency (Ruiz et al 1994). Currently, management of advanced cervical cancer has not been optimal. Emerge of depression often be unrecognized and not given serious treatment because there is assumption that depression is a common condition as an universal reaction towards serious disease (Krebs 2003).

Cognitive Behavioral Therapy (CBT) as a psychotherapy which focuses on problem is made to reduce symptoms and to build faith that someone has control of mind, believe, behavior and skill in order to help patient during cancer therapy. CBT roles in advanced cervical cancer therapy are expected to make a positive impact, thus can reduce the stress level in patient who will undergo treatment. Process of positive impact occurrence after CBT in cervical cancer patient currently can not be explained, particularly in biomolecular term. This study aimed to explain biomolecularly, notably about serum serotonin in advanced cervical cancer patients who had underwent CBT.

\section{MATERIALS AND METHODS}

Experimental double blind randomized clinical trial pre and post test group design. Study subjects were advanced cervical cancer patients (stadium IIB-IV), chosen using nonprobability sampling with consecutive sampling methods (subjects came in sequence and met inclusion criteria were included to study until the number of subjects required were fulfilled). Inclusion criteria include: first episode of depression (assessed by BDI score) without history of treatment before, communicate well, speak Indonesian, willing to be involved in the study. Patients who suffer from severe mental illness (psychotic), cancer in the other organ, pregnant, or ever underwent therapy for depression were excluded. Number of 15 subjects were allocated to two groups. The intervention group was given CBT and standard therapy, while the control group was given standard therapy only. Intervention was being done by a competent psychiater. Outcomes were serotonin level, depression score using BDI score, and quality of life (QOL) using WHOQOL-BREF before and after intervention. Collected data was processed by SPSS program. We used independent $t$ test to analyze pre and post test study variables. Independent variable was CBT intervention, dependent variable were serotonin level and pain score using Wong Baker Faces Pain Scale.

Study was held in ward and polyclinic of Obstetric and Gynecology in Dr. Moewardi Hospital Surakarta, as well as Prodia Laboratory, at March 2015 until the subject quota was fulfilled, after got the agreement from ethical committee Faculty of Medicine UNS Surakarta.

\section{RESULTS}

Table 1. Characteristics of Intervention Subjects

\begin{tabular}{llcc}
\hline \multicolumn{1}{c}{ Variable } & \multicolumn{1}{c}{ Category } & $\mathrm{N}$ & $\%$ \\
\hline Age & < 50 years old & 4 & 26.7 \\
& $>50$ years old & 11 & 73.3 \\
Employment status & Work & 9 & 60.0 \\
& Housewife & 6 & 40.0 \\
Education level & No school & 6 & 40.0 \\
& Elementary & 6 & 40.0 \\
\multirow{5}{*}{ Parity } & Secondary & 3 & 20.0 \\
& Biparous & 6 & 40.0 \\
& Multi & 9 & 60.0 \\
\hline
\end{tabular}

Table 1 shows that most of the intervention subjects were more than 50 years old, 11 cases $(73.3 \%)$, work 9 cases $(60 \%)$, no school 6 cases $(40.0 \%)$ and multigravida 9 cases $(60.0 \%)$.

Table 2. Data Normality Test Shapiro Wilk of Serotonine Level in Advanced Cervical Cancer Patients Before and After CBT Psychotherapy

\begin{tabular}{lll}
\hline Group & $\mathrm{N}$ & $\mathrm{P}$ \\
\hline Before Psychotherapy & 15 & 0.138 \\
After Psychotherapy & 15 & 0.321 \\
\hline
\end{tabular}


Table 2 shows that serotonine level before and after intervention were normally distributed $(p>0.05)$ thus we used parametric test independent $t$ test.

Table 3. Independent t test of Serotonine Level Before and After CBT

\begin{tabular}{lllcc}
\hline Group & N & Mean & SD & Sig \\
\hline Before Psychotherapy & 15 & 89.57 & 23.23 & $0.000^{*}$ \\
After Psychotherapy & 15 & 219.43 & 33.42 & \\
\hline
\end{tabular}

Table 3 shows that there was difference of serotonin level before and after intervention, statistically significant $(\mathrm{p}<0.05)$.

Table 4. Data Normality Test Shapiro Wilk of BDI Score in Advanced Cervical Cancer Patients Before and After CBT

\begin{tabular}{llc}
\hline Group & $\mathrm{N}$ & $\mathrm{P}$ \\
\hline Before Psychotherapy & 15 & 0.197 \\
After Psychotherapy & 15 & 0.061 \\
\hline
\end{tabular}

Table 4 presents a fact that BDI score data in both groups were normally distributed $(p>0.05)$ so we used statisctical parametric independend t test.

Tabel 5. Independent t test of BDI Score Before and After CBT

\begin{tabular}{ccccc}
\hline Group & N & Mean & SD & Sig \\
\hline Before Psychotherapy & 15 & 17.00 & 4.86 & $0.000^{*}$ \\
After Psychotherapy & 15 & 11.20 & 4.94 & \\
\hline
\end{tabular}

Table 5 shows that there was a significant difference of BDI score before and After CBT $(\mathrm{p}<0.05)$.

Table 6. Data Normality Test Shapiro Wilk of Quality of Life Score in Advanced Cervical Cancer Patients Before and After CBT

\begin{tabular}{ccc}
\hline Group & $\mathrm{N}$ & $\mathrm{P}$ \\
\hline Before Psychotherapy & 15 & 0.560 \\
After Psychotherapy & 15 & 0.881 \\
\hline
\end{tabular}

Table 6 shows that data about quality of life score before and after CBT was normally distributed ( $>>0.05)$ so that we used parametric independent $t$ test for statistical analysis.

Table 7. Independent $t$ test for Quality of Life (QOL) Score Before and After CBT

\begin{tabular}{lcccc}
\hline Group & N & Mean & SD & P \\
\hline Before Psychotherapy & 15 & 41.86 & 7.24 & 0.000 \\
After Psychotherapy & 15 & 85.13 & 14.62 & \\
\hline
\end{tabular}

Table 7 shows that there was a significant difference of QOL score before and after CBT $(\mathrm{p}<0.05)$.

\section{DISCUSSION}

Study performed in Dr. Moewardi Hospital used advanced cervical cancer patients who eligible to the inclusion and exclusion criteria as study subjects. After analysis of study data, it is shown that there was significant difference between the two groups: mean serotonin level before and after CBT intervention ( $\mathrm{p}<0.05)$. This indicated that CBT intervention in cervical cancer patient was proven to be effective in improving serotonin level, so that it can increase the life expectancy.

Previous study held measured serum cortisol level in advanced cervical cancer patient after CBT intervention compared with standard therapy, showed a very significant difference $(\mathrm{p}=0.000)$ (Pramudhita 2015). Another study in Dr.Moewardi Hospital compared difference of cortisol level before and after CBT intervention in cervical cancer patients presented $\mathrm{p}=$ 0.001 , indicating a very significant difference after CBT intervention (Irianto 2015). Advanced cervical cancer patients experience a tremendous emotional stress lead to reduction of their QOL due to long term therapy. Cervical cancer patients undergo chemotherapy are in terrific biological and emotional stress condition that can lead to reduction of serotonin level (Limberaki 2011). Acute stress will reduce the sertotonin level acutely and inhibit immune system, while psychological stressor will reduce serotonin level gradually and inhibit immune system (Soetrisno 2009).

Beck Depression Inventory score in advanced cervical cancer patients showed a difference before and after CBT intervention with the mean score after CBT was lower compared to before CBT. Statistical test result was $\mathrm{p}=0.000$, indicating a very significant difference. This result revealed that $\mathrm{CBT}$ intervention can reduce BDI score in advanced cervical cancer patients. The BDI score reduction after CBT intervention can reduce depression level so that patients' quality of life can be improved. Women with cervical cancer, particularly advanced stage, will experience an emotional stress that lead to the reduction of quality of life, because they have to undergo long term treatment with low cure rate. The emerging emotions are depression of life uncertainty, afraid of future, anxiety, doubt, angry due to loss of reproduction function, guilt of the previous sexual activity that might cause cancer, and mixed feeling about future sexual activity disturbance after cancer treatment (Prawiroharjo 2010). These exactly can affect patient's quality of life.

Analysis about quality of life score using World Health Organization scale on Quality of Life-BREF (WHO QOL-BREF) showed an enhancement after CBT 
intervention with $\mathrm{p}$ value $=0.000$, indicating a very significant difference of QOL before and after CBT. Measurement of QOL with WHOQOL-BREF instrument is valid and reliable. This is consistent with Oktavianus et al (2007) opinion about validity and reliability of WHOQOL-BREF to assess quality of life.12 This study result showed that CBT intervention in advanced cervical cancer patients can enhance serotonin level, reduce depression score and improve quality of life. Serotonin is neurotransmitter from one to another part of brain and expected to have an active role in regulating behavior towards response from stress exposure and associated with depression that can affect quality of life. Serotonin is originated from dorsal and median raphe nucleus in midbrain. When ther is stress exposure, serotonin activity is increased, proved with the enhancement of gen expression in dorsal raphe nucleus (Ruiz et al 1994).

Cognitive Behavioral Therapy (CBT) is a precept therapy in depression patient. This therapy helps someone identify negative thoughts as wrong and deviate thoughts, then try to substitute them with more positive thoughts which can make someone feel better. Study limitations i.e not using study subjects with similar characteristics like age, job, education, parity, cervical cancer stage, which can influence treatment result. Still, could not control other confounding factors like nutrition status, laboratory result, and family history that can affect patient's risk for experiencing stress.

\section{CONCLUSION}

Can be concluded that there were enhancement of serotonin level, reduction of depression score, and improvement of quality of life in advanced cervical cancer patients underwent CBT intervention. CBT is expected to be applied in advanced cervical cancer patient in hospital in order to improving patient's quality of life so that can increase the five survival rate. Need a further investigation regarding CBT intervention in advanced cervical cancer with controlling various confounding factors.

\section{REFERENCES}

Himpunan Onkologi Ginekologi Indonesia. 2013. Panduan Pelayanan Klinik Kanker Ginekologi. Jakarta: Himpunan Onkologi Ginekologi Indonesia.

IARC, 2005. Handbook of Cancer Prevention. Cervical Cancer Screening. International Agency for Research on Cancer World Health Organization. IARC Press.

Irianto B, 2015. Pengaruh Cognitive Behavioural Therapy (CBT) Terhadap Kadar Kortisol dan Skor Beck Depression Inventory Pada Pasien Kanker Serviks Stadium Lanjut. Tesis, Universitas Sebelas Maret Surakarta.

Krebs, 2003. Management of Concomitant Depression and Physical Illness, WPA Bulletin on Depression, Depression in General Practice, 24-6

Limberaki, 2011. Cortisol Levels and Serum Antioxidan Status Following Chemotherapy. Vol.3, No.8, 512517 (2 doi:10.4236/health.2011.38085 Copyright (C) 2011 SciRes. Openly accessible at http://www.scirp. org/journal/HEALTH 011).

Oktavianus C, Novia I, Sudharmana, Rina K. Kusumaratna dan Adi Hidayat, 2007. Validitas dan reliabilitas World Health OrganizationQuality of LifeBREF untuk mengukur kualitas hidup lanjut usia. Universa Medicina. 2007

Pramudhita R, 2015. Perbedaan Kadar Kortisol Serum Pasien Kanker Serviks Stadium Lanjut Setelah Intervensi Cognitive Behavior Therapi (Cbt) Dengan Terapi Standar, Tesis, Universitas Sebelas Maret

Prawiroharjo S, 2010. Buku Acuan Nasional Onkologi dan Ginekologi. Jakarta: Balai Penerbit Bina Pustaka Jakarta: 442-54.

Ruiz, Juan Carlos., Santafe, Juan., Domenech, Josse Segarra. Modification of Rat Plasma Lipoprotein Induced by Acute Immolizatism Stress. Arantza Phsychosomatic Medicine 1994 (56): 486-492.

Schiff D, 2003. Cancer neurology in clinical practice, Humana Press Inc. New Jersey

Soetrisno, 2009. Ekspresi Heat Shock Protein 60,70,90 dan Kortisol pada Persalinan Ibu Primigravida yang Mendapat Psikokuratif. Disertasi.Surabaya: Universitas Airlangga.

Surveillance Epidemiology and End Result Program (SEER), 2012. Cervix Uteri Cancer. National Cancer Institute. 